\title{
PROMPTED TO BE GOOD: THE IMPACT OF CERTIFICATION ON THE QUALITY OF CHARITIES
}

Katarína Svítková
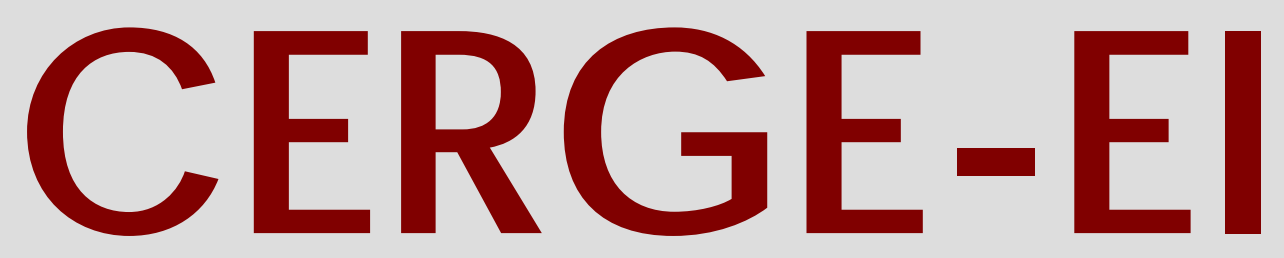

Charles University Centerfor Economic Research and Graduate Education Academy of Sciences of the Czech Republic Ec onomic s Institute 


\section{Working Paper Series 320 (ISSN 1211-3298)}

\section{Prompted to Be Good: The Impact of Certification on the Quality of Charities}

Katarína Svítková

CERGE-EI

Prague, March 2007 
ISBN 978-80-7343-117-4 (Univerzita Karlova. Centrum pro ekonomický výzkum a doktorské studium)

ISBN 978-80-7344-106-7 (Národohospodářský ústav AV ČR, v. v. i.) 


\title{
Prompted to Be Good: The Impact of Certification on the Quality of Charities*
}

\author{
Katarína Svítková ${ }^{\dagger}$ \\ CERGE-EI
}

\author{
AAV $\check{S}^{\S}$
}

March 2007

\begin{abstract}
In this study we model how certification affects managers' choice of the quality of the nonprofit organizations they run. We analyze a market with one representative charity, run by a manager with some preference for the provision of a charitable good, one donor, and a certification agency. We assume that the nature of the charitable good does not allow for partial provision, thus, the charity can be of two types only: a good charity that spends all its resources on the charitable good, and a bad one that diverts all its resources for the private consumption of its manager (for-profit in disguise). We show that for a wide parameter range, the presence of an honest certifier in the market increases the incentives for managers to choose good charities, leading to an improvement in the market as the share of good charities increases.
\end{abstract}

Keywords: quality assurance, certification, moral hazard, experience goods JEL classification: C72, D21

*The author would like to thank Marc Bilodeau, Randal Filer, Andreas Ortmann, and Rich Steinberg for helpful comments.

${ }^{\dagger}$ Email: katarina.svitkova@cerge-ei.cz

${ }^{*}$ A joint workplace of the Center for Economic Research and Graduate Education, Charles University, Prague, and the Economics Institute of the Academy of Sciences of the Czech Republic, v. v. i.

Address: CERGE-EI, P.O. Box 882, Politických vězňů 7, Prague 1, 111 21, Czech Republic

${ }^{\S}$ The New Anglo-American College in Prague, Lázeňská 4, Prague 1, 118 00, Czech Republic 


\begin{abstract}
Abstrakt
V tejto štúdií modelujeme dopad certifikácie na manažérovo rozhodnutie o kvalite neziskovej organizácie, ktorú riadi. Analyzujeme modelovú situáciu s jednou reprezentatívnou neziskovou organizáciou (charitou), ktorá je vedená manažérom $\mathrm{s}$ istými danými preferenciami k poskytovaniu charitatívneho produktu, jedným darcom, a certifikacnou agentúrou. Predpokladáme, že charakteristika tohoto produktu neumožnuje jeho ciastocné poskytovanie. A teda, nezisková organizácia môže mat len jednu z dvoch foriem: dobrá nezisková organizácia, ktorá využíva všetky svoje zdroje na poskytovanie charitatívneho produktu, a zlá nezisková organizácia, ktorá zneužíva všetky svoje zdroje na privátnu spotrebu svojho manažmentu. V tejto štúdií ukazujeme, že pre širokú škálu hodnôt parametrov prítomnost certifikacnej agentúry vplýva pozitívne na situáciu na trhu tak, že zvyšuje manažérovu motiváciu zaistit vyššiu kvalitu neziskovej organizácie, ktorú vedie, a tým celkový podiel dobrých organizácií na trhu.
\end{abstract}




\section{Introduction}

We explore a specific aspect of the problem of asymmetric information that arises between donors and charities collecting donations. The problem arises because donors typically can not observe the quality of an organization they might want to support. Following the logic of Akerlof (1982), they might give according to what they believe is the average quality of organizations in the market. This brings about various inefficiencies: charities of low quality receive too many donations, charities of high quality receive too few, and donors might give less than they would if quality was observable. Several mechanisms have evolved to mitigate this problem, ranging from the non-distribution constraint imposed on non-profit organizations to prevent spending of donations on other than charitable purposes, to more explicit regulations such as the requirement of the IRS to publish Form 990 designed to control the operation of charities and, among other things, to enforce the non-distribution constraint. As summarized in Ortmann, Svitkova and Krnacova (2005), none of these solutions is without its problems. We, therefore, focus on a solution that seems to avoid most of the drawbacks, certification: an independent third party, the certifier, provides a costly signal, the certificate, to charities in the market. The charities may choose to apply for certification, and, if they pass the evaluation, use the certificate to signal their quality to donors.

The operation of a certification agency and the design of a certification system brings about a number of questions. Svitkova and Ortmann (2006) analyze some of them: a certifier's choice of certification system, its quality and price as a function of optimization functions he might have, and the impact on the welfare of the society. That study, however, omits an important aspect of certification: if and how certification affects the quality of charities in the market. In other words, it analyzes an adverse selection problem, assuming charities' quality is given exogenously. Although we are not aware of any persuasive evidence, intuition suggests that certification does affect the quality of the organizations in the market. In the present study, we therefore relax the assumption of exogenously given quality and allow for an analysis of the moral hazard problem.

Specifically, we study how certification affects the manager's choice of the quality of the nonprofit organization he runs. We show that under a wide parameter range, the presence of a certifier in the market increases incentives for managers to run a good charity, leading to an increase in the number of good charities.

The manuscript is structured as follows: Section 2 lists the assumptions of the model, Section 3.1 describes the model, its timing and structure and results. 
Section 3.2 summarizes the choice of the charity; Section 3.3 analyzes the decision of the manager. Section 4 concludes.

\section{Assumptions}

We analyze a game with four players: donor, charity, manager, and certifier. The timing and detailed structure of the game follows below.

We study the decision of one representative manager, who determines the quality of the organization he runs to maximize his utility. The manager is uniquely identified by his preference for the provision of a charitable good, $\alpha$, a random variable with uniform distribution on the unit interval $[0,1]{ }^{1}$

We assume that the utility function of the manager is a convex combination of private consumption, $X$, and a charitable good, $Q$. Thus, $U(X, Q)=\alpha Q+(1-\alpha) X$. We assume that the manager maximizes his utility subject to a budget constraint and that the only source of revenues for the charity is fundraising, i.e., received donations net of the costs of fundraising.

If there is certification in the market, the charity ${ }^{2}$ decides whether to apply (which is costly). Other-wise, the charity has no decision to make. The charity maximizes its expected net revenue, therefore, it tries to attract as many donations as possible. How it spends the money depends on the type of the charity and, ultimately, on the preference of the manager.

For simplicity, we assume that the nature of the charitable good does not allow for partial provision. Therefore, the charity either spends all resources on the provision of the charitable good or it does not spend any at all. Thus, the charity has either quality 1 ('good') or quality 0 ('bad'). A good charity is a nonprofit organization that cares about the provision of the charitable good. A bad charity is a 'for-profit in disguise' (Weisbrod 1988) that exists to maximize the income of its manager by abusing the nonprofit status and the trust of donors. We assume that the quality of the charity cannot be changed once it has been set. ${ }^{3}$

The certifier chooses the certification fee, $c,{ }^{4}$ and detection technology, $p$, to

\footnotetext{
${ }^{1}$ This assumption is a simplified version of the assumption of heterogeneity of nonprofit managers; see Young (1983).

${ }^{2}$ The charity is run by the representative manager.

${ }^{3}$ This assumption ensures that the moral hazard problem is solved, i.e., that the charity indeed changes its quality. This assumption does not contradict reality: in a market without certification, a charity has no reason to change its quality which has been chosen according to the manager's preference; in a market with certification, the certifier performs repeated checks of quality ensuring that the charity maintains the promised standard.

${ }^{4}$ The observed certification agencies typically charge a fee that increases with the size of the
} 
evaluate the applying charities. We do not analyze how the certifier makes this decision; we examine how these parameters affect the choices of the other players. ${ }^{5}$ The certifier issues a certificate to the charities that apply for certification, pay certification fee $c$, and pass the evaluation.

We assume, in line with what we observe (Guet 2002), that the certifier evaluates charities on a number of indicators using the detection technology, but he summarizes the result into a single number in the interval $[0,1]$. We denote this number $q$, for the quality of the charity. It represents the probability that the charity is of high quality. ${ }^{6}$ Based on this probability, the certifier awards or denies the certificate.

The quality of the detection technology is captured by $p$, the probability that a charity is awarded the certificate when it is entitled to it. Thus, a good charity is awarded the certificate with probability $p$, a bad charity is awarded the certificate by mistake, i.e., when it is not entitled to it, with probability $1-p .^{7}$ We assume that the probability of a mistake is smaller than the probability of correct identification, i.e., $p \in\left[\frac{1}{2}, 1\right] .^{8}$

For simplicity we assume one representative donor (supporting one representative charity). ${ }^{9}$ She decides how much to donate to maximize her utility from the charitable good. We assume that she wants to support the provision of the charitable good, but she understands that its quality depends on the quality of the pro-

charity (usually, it is composed of a fixed and a proportional part, Guet (2002)), thus, the fee for a charity of 'unit' size remains relatively stable. To simplify the analysis, we assume the fee is constant.

${ }^{5}$ For an analysis of a certifier's choice for various objective functions, see Svitkova and Ortmann (2006).

${ }^{6}$ We refer to this number also as the expected quality of the charity.

${ }^{7} \mathrm{We}$ assume, for simplicity, that the detection technology is symmetric, i.e., the probability that a good charity is evaluated as good is equal to the probability that a bad charity is evaluated as bad. We maintain this assumption because we think that what matters in evaluation is the distance from the standard, rather than the direction of this difference: it is difficult to observe the quality of organizations at the standard, but it is easy to discover the very good or very bad organizations. Nevertheless, we will consider the implications of different detection functions in future work.

${ }^{8}$ The probability of correct identification, $p$, is derived from a detection procedure in the following manner: Let $\varepsilon$ denote the range of possible probabilities the certifier may assigned to a charity he evaluates, i.e., it is the range of possible $q$. We assume that a good charity is assigned, based on the evaluation, $q$ distributed uniformly in the interval $[1-\varepsilon, 1]$, a bad charity $q$ in the interval $[0, \varepsilon]$. We assume $\varepsilon \in\left[\frac{1}{2}, 1\right]$. The best technology, $\varepsilon=\frac{1}{2}$, ensures that the certifier is certain about the quality of the evaluated charity, otherwise, he makes mistakes. From the assumption that the observable $q$ is distributed uniformly follows $p=\frac{1}{2 \varepsilon}$ and $1-p=1-\frac{1}{2 \varepsilon}$; $\varepsilon \in\left[\frac{1}{2}, 1\right]$ implies $p \geq 1 / 2$, i.e., a good charity is awarded the certificate more often than a bad one for all detection technologies.

${ }^{9}$ Assuming a representative donor avoids the problem of free riding, which often occurs in fundraising. We use this simplifying assumption to be able to focus on the moral hazard problem. 
viding charity. Specifically, the donor realizes that supporting a bad charity means zero provision of the charitable good, while supporting a good one maximizes its provision and quality. We do not study why the donor supports the charitable good; we assume that her utility is maximized when she gives 1 (normalized amount) to a good charity and that she obtains no utility from supporting a bad charity. Thus, we consider only the utility that arises from the charitable good. It is a function of the charity's expected quality, $p . U(p), U^{\prime}(p)>0, U(1)=U_{\max }, U(0)=U_{\min }=0 .{ }^{10}$

The utility of the donor, and hence her donation, increases with the expected quality of the charity and reaches its maximum (normalized to 1) at the highest quality, 1. Giving is identical to the utility obtained from supporting a charity that is good with probability $p, g(p)=U(p)$.

Since the donor cannot observe the quality of the charity she wants to support, she gives according to the information she has. In a market without certification, she knows only the average quality of the charity in the market. ${ }^{11}$ Due to this asymmetric information problem, the donor donates less than she would if she was certain tha the charity was good.

In a market with certification, the donor obtains additional information: she observes also whether the charity has the certificate, the certification fee, and the detection technology. ${ }^{12}$ She uses this information to update her prior beliefs about the quality of the charity, and gives accordingly. If the certifier ensures that only a charity of high quality receives the certificate, the donation to the certified charity is the highest possible, $1 .^{13}$ However, as there are mistakes in the evaluation technology, and the donor cannot observe whether the non-certified charity did not apply for certification or it applied but failed the evaluation (due to a mistake), ${ }^{14}$ the

\footnotetext{
${ }^{10}$ The assumption that donors appreciate quality is based on empirical evidence from the Netherlands, where donors increased their giving to certified charities after they learned about the certification (Bekkers (2006); Bekkers (2003)). An alternative assumption would be that donors want to maximize provision of the charitable good, not caring for the quality of charities (it is necessary to give more to less efficient organizations because they need more funds to provide the same result as good charities). But, then the donors would give most to the bad charity and gain no provision at all, which seems very unusual.

${ }^{11}$ Alternatively, if we assumed a market with a range of charities, the donor would know what fraction of charities was good, but she would not be able to observe the quality of an individual charity.

${ }^{12}$ We assume that the certifier does not disclose any additional information about the evaluation. The donor obtains only a binary signal: certificate/no certificate. This assumption is based on the observed reality (Svitkova and Ortmann 2006). In Section 3.4, we analyze the case with an alternative disclosure rule, where the donor observes also whether the charity applied for certification.

${ }^{13}$ The certifier is in reality never able to ensure perfect detection. We discuss the case for theoretical purposes only.

${ }^{14}$ This assumption is in line with what we observe in certification markets, (Guet 2002).
} 
probability that a good charity remains without the certificate is positive. Thus, a non-certified charity receives a positive donation.

With the worst detection technology, $p=\frac{1}{2},{ }^{15}$ the probability that a good charity receives the certificate is equal to the probability that a bad charity receives it. The probability that a good charity fails to pass the evaluation is the highest possible, and the donor makes the smallest difference in her support of certified and non-certified organizations. With perfect detection, $p=1,{ }^{16}$ a good charity is always awarded the certificate. The donor relies on the signal and gives a donation to the certified charity only; the difference between her support of a good and a bad charity is the highest, 1 .

\section{Model and results}

\subsection{Timing of the game}

1. The preference of the manager, $\alpha$, is randomly drawn from a uniform distribution over $[0,1]$. The conditions of the certification system are set: the fee for certification, $c$, and the quality of detection technology, $p$.

2. The manager determines the quality of the charity he runs, he decides between a good charity, of quality 1 , and a bad one, of quality 0 , maximizing his utility function.

3. The charity (manager) chooses whether to apply for certification, maximizing its expected net revenues.

4. If the charity has applied for certification and paid the fee, the certifier evaluates it and awards the certificate if it passes the evaluation.

5. The donor adjusts her beliefs about the quality of the charity based on the information she receives: whether the organization has been certified, the certification fee, and the quality of detection technology. She gives accordingly.

To observe the impact of certification on the quality of charities in the market, we need to identify the manager, who is indifferent between choosing a good or a bad charity. We denote him by $\alpha_{I}$ and observe whether this $\alpha_{I}$ changes with

\footnotetext{
${ }^{15}$ The certifier has no additional information, $\varepsilon=1$; the result of his evaluation may be anywhere in the interval $[0,1]$ for both types of charity.

${ }^{16} \varepsilon=1 / 2$
} 
certification. We solve the game in two steps. First, we solve for the optimal strategy of the charity in the subgame between the charity and the donor given the certification system. ${ }^{17}$ Second, we solve the full game, identifying the equilibrium strategy of the manager, and the indifferent manager $\alpha_{I}$, which defines the expected quality of the charity in the market. For comparison we start with the benchmark case- the market without certification.

\subsection{Decision of a charity}

\subsubsection{No certification}

In the market without certification, the donor knows the initial probability that the charity is good; we denote it $d$. But, she cannot observe the true quality of the charity, does not get any additional information, and, therefore, gives according to her expectations, $g(d)$. In this case the charity does not have any decision to make.

\subsubsection{Certification}

In the market with certification, a charity decides whether to apply for certification and send the donor a signal about its quality. If it applies for certification, it goes through the evaluation process and obtains the certificate with probability $p$ if it is a good charity, and probability $1-p$ if it is a bad charity. The charity chooses the strategy that ensures higher expected payoff. The subgame has three equilibria: A separating equilibrium, in which only the good charity applies; a pooling equilibrium, in which both types apply; and a pooling equilibrium, in which both types do not apply.

The separating equilibrium arises if only the good charity applies for certification and the bad charity does not apply. The equilibrium is characterized by the following incentive compatibility constraints:

$$
\begin{aligned}
& E[A \mid 0] \leq E[N A \mid 0] \Leftrightarrow(1-p)+p g_{N C}-c \leq g_{N C} ; \\
& E[A \mid 1] \geq E[N A \mid 1] \Leftrightarrow p+(1-p) g_{N C}-c \geq g_{N C} .
\end{aligned}
$$

Constraint (1) requires that the bad charity is better off not applying (NA) for certification. Constraint (2) requires that the good one is better off applying (A). In the separating equilibrium, the charity with the certificate is known to be of quality 1 , thus, it obtains the highest possible payoff, 1 . The non-certified charity

\footnotetext{
${ }^{17}$ This subgame starts in step 3.
} 
can be either good or bad, its payoff, $g_{N C}$, depends on the probability that it is good, $g_{N C}=g(\operatorname{Prob}[1 \mid N C])$. If $d$ denotes the initial probability of a good charity in the market, then

$$
\operatorname{Prob}[1 \mid N C]=\frac{\operatorname{Prob}[1] \operatorname{Prob}[N C \mid 1]}{\operatorname{Prob}[0]+\operatorname{Prob}[1] \operatorname{Prob}[N C \mid 1]}=\frac{d(1-p)}{1-d p} .
$$

Both constraints have to be satisfied to induce the separating equilibrium. Simplifying and rearranging, we derive the condition for the certification fee, $c:^{18}$

$$
c_{\min }=(1-p)\left(1-g_{N C}\right) \leq c \leq p\left(1-g_{N C}\right)=c_{\max }
$$

Intuitively, the certification fee that induces separation increases as the difference in the payoff to the certified and non-certified charity increases because an increase in this difference means that the incentives for the bad type to apply for certification (and possibly obtain the certificate ensuring higher payoff) increase. In order to induce separation in this case, the certifier has to charge a higher fee. The quality of the detection technology, $p$, increases the range of fees the certifier may charge. A certifier with perfect technology, $p=1$, may charge any fee in the interval $[0,1]$ and still induce separation because he relies solely on evaluation, not on the fee. With technology of lower quality, the certifier's reliance on the fee increases, decreasing the range of fees he may charge. The worst technology, $p=\frac{1}{2}$, leaves no choice - the only fee inducing separation is $c=\frac{1}{2}\left(1-g_{N C}\right)$.

If the certifier charges a fee below $c_{m i n}$, the incentive compatibility constraint for the bad type, inequality (1) is not satisfied. In this case, the game has either no equilibrium in pure strategies, or a pooling equilibrium with both types of charities applying. In the pooling equilibrium, even though both types apply for certification, they are awarded the certificate with different probabilities. The donor evaluates the expected probability that a charity with and without the certificate is good and gives accordingly. The payoffs in the pooling equilibrium are the following:

$$
\begin{gathered}
g_{C p}=g\left(\frac{d p}{d p+(1-d)(1-p)}\right) \\
g_{N C p}=g\left(\frac{d(1-p)}{d(1-p)+(1-d) p}\right) \cdot{ }^{19}
\end{gathered}
$$

\footnotetext{
${ }^{18}$ If the certifier sets a fee in this interval, a separating equilibrium exists.

${ }^{19} g_{C p}=g(\operatorname{Prob}[1 \mid C])=g\left(\frac{\operatorname{Prob}[1] \operatorname{Prob}[C \mid 1]}{\operatorname{Prob}[1] \operatorname{Prob}[C \mid 1]+\operatorname{Prob}[0] \operatorname{Prob}[C \mid 0]}\right) ;$

$g_{N C p}=g(\operatorname{Prob}[1 \mid N C])=g\left(\frac{\operatorname{Prob}[1] \operatorname{Prob}[N C \mid 1]}{\operatorname{Prob}[1] \operatorname{Prob}[N C \mid 1]+\operatorname{Prob}[0] \operatorname{Prob}[N C \mid 0]}\right)$.
} 
The participation constraints defining the pooling equilibrium look as follows:

$$
\begin{gathered}
(1-p) g_{C p}+p g_{N C p}-c \geq g_{N C p} \\
p g_{C p}+(1-p) g_{N C p}-c \geq g_{N C p} .
\end{gathered}
$$

Constraint (6) ensures participation of the bad type. Because the expected payoff of the bad type is always below that of the good type, the good type participates whenever the bad type participates (Constraint (7) is satisfied). We denote the fee at which the constraint (6) binds $c_{\text {max }, p}$.

If the certifier charges a fee in the interval $\left[c_{\max , p}, c_{\min }\right]$, there does not exist an equilibrium in pure strategies. While the good charity always applies, the bad one chooses to apply with some probability (less than one).

If the certifier charges a fee above the maximum fee guaranteeing separation, $c_{\text {max }}$, then neither the bad nor the good type applies for certification. Certification in this case has no effect on the situation in the market, and we do not need to consider this case any further.

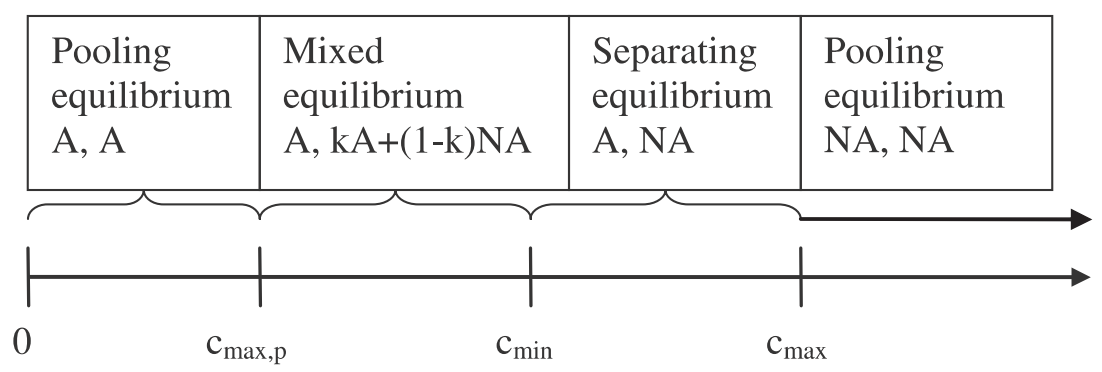

Figure 1: The impact of the certification fee on equilibrium

\subsection{Decision of the manager}

In this section we analyze the manager's choice of the quality of the organization he runs. We identify the manager who is indifferent between running a good and a bad charity, $\alpha_{I}$, the type of the indifferent manager defines the quality of the organization in the market, $d . d=1-\alpha_{I}$, i.e., the probability that the charity in the market is good, $d$, equals the probability that the manager prefers to run a good charity - his $\alpha$ is above the threshold $\alpha_{I}$. Again, we first consider the benchmark case without certification, $d_{N C}$, then we observe how it changes in a market with certification, $d_{C}$. 
The manager chooses the type of organization that maximizes his utility, comparing

$$
\begin{array}{r}
U(X, Q \mid 0)=(1-\alpha) X ; \quad \text { s.t. : } E[. \mid 0] \geq X ; \\
U(X, Q \mid 1)=\alpha Q ; \quad \text { s.t. : } E[. \mid 1] \geq Q .
\end{array}
$$

The bad charity, of quality 0 , spends all collected donations on private consumption, generating utility $(1-\alpha) X$. The good charity, of quality 1 , spends all funds on the provision of the charitable good, generating utility $\alpha Q$. The expected payoff of the charity, $E[. \mid 0 / 1]$, depends on the type of equilibrium induced (pooling or separating), and the type of charity, thus its action (applies for the certificate, pays the fee, does not apply, does not pay the fee). The payoffs were summarized in the previous section (e.g., equations (1), (2)).

\subsubsection{No certification}

In the market without certification the donor has no additional information and cannot distinguish between a good and a bad charity, the payoffs to the two types are, therefore, equal. The indifferent manager, $\alpha_{N C}$, derives equal utility from running a good and a bad organization; the equilibrium arises at $\alpha_{N C}=1-d_{N C}=$ $\frac{1}{2}=d_{N C}$.

\subsubsection{Certification}

The impact of certification on the decision of the manager, $\alpha_{C}$, and thus the quality of the charity in the market, $d_{C}$, depends on the detection technology, $p$, and the certification fee, $c$, as specified in the following proposition:

Proposition: Certification with a fee below $c_{\max , p}$, increases the expected quality of the organization in the market, $d_{C}>d_{N C}$, for all detection technologies with $p>\frac{1}{2}$. Quality increases as the fee increases. An improvement in the detection technology, $p$, increases the expected quality.

Certification with a fee in the interval $\left[c_{\max , p}, c_{\min }\right]$, the mixed equilibrium, increases the expected quality of the organization in the market. The impact decreases with the fee, $c$. 
Certification with a fee in the interval $\left[c_{\min }, c_{\max }\right]$, the separating equilibrium, increases the expected quality of the organization in the market, $d_{C}>d_{N C}$, for all detection technologies with $p>\frac{1}{2}$. An increase in the certification fee within the interval decreases the expected quality. An improvement of the detection technology, $p$, increases the expected quality.

Certification with a fee at and above, $c_{\max }$, has no impact on the quality of the organization in the market, $d_{C}=d_{N C}$, for all qualities of detection technology. Similarly, certification with the worst detection technology, $p=\frac{1}{2}$, has no impact on the quality of the organization in the market. The result does not depend on the fee.

Certification with a fee below $c_{\max , p}$ leads to a pooling equilibrium (see Section 3.2.2). Certification in this case, despite the fact that both types apply for certification, brings additional information because the certifier awards the certificate more often to the good charity. The donor, therefore, ends up giving more to the good charity. The difference in the payoff to the good and the bad charity increases in the quality of detection technology, as better detection means that the probability of a good charity having the certificate is higher. An increase in the certification fee has the same effect on the payoffs of both charities, but because the probability that a bad type receives the certificate is lower, his expected payoff is lower. An increase in the certification fee, though, has a different impact on the utility of managers running good and bad charities. The difference depends on his preference for the charitable good, $\alpha$. Managers with $\alpha<\frac{1}{2}$ running a bad charity, i.e., getting utility $(1-\alpha) X$, suffer more from an increase in the fee than managers with higher $\alpha$. Therefore, increasing the fee decreases the incentives to start a bad charity for managers with low preference for the charitable good; the effect is the strongest at the highest fee ensuring pooling equilibrium, $c_{\max , p}$. The effect increases with the quality of the detection technology as illustrated in Figure 2 (below, the dashed line).

Certification with a fee in the interval $\left[c_{\min }, c_{\max }\right]$, see $(3)$, leads to a separating equilibrium. In this case only the utility of the manager choosing a good charity decreases with the fee for certification. The utility of the manager running a bad charity is not directly affected by the fee because the bad charity does not apply for certification. Thus, the difference in the payoff to the good and the bad charity decreases as the fee increases. Therefore, it is sufficient to consider the effect of certification in the two polar cases, when the certifier charges the highest and the 
lowest fee leading to separation.

If the certifier charges the highest fee (the good charity is indifferent about applying, the incentive compatibility constraint (2) holds with equality), he extracts the whole surplus that the charity gains from the certificate. The expected payoff of the charity with the certificate, thus, the utility from running such a charity, is the same as it would be in the market without certification. Thus, the probability that a charity is good, $d_{C}$, and the manager who is indifferent, $\alpha_{C}$, also remain the same. The result is independent of the detection technology, $p$. The only service provided by the certifier is information provided to the donor, who learns something about the charity she supports. Nevertheless, this has no effect on the final provision of the charitable good because, even though the donor gives more if she learns that the charity is good, the surplus donation ends up in the pocket of the certifier.

If the certifier charges the lowest fee ensuring separation (the bad charity is indifferent about applying, the incentive compatibility constraint (1) holds with equality), the utility from running a good charity is significantly above that from running a bad one because the certifier leaves the surplus brought by the certificate to the charity. Therefore, even a manager with a weaker preference for the charitable good prefers to run a good charity. The analytical solution defining $\alpha_{C}$, thus $d_{C}$, exists, but it does not have any intuitive form, therefore, we illustrate it in Figure 2 (the full line). The probability that a charity is good is above the benchmark case with no certification, i.e., the indifferent manager has lower preference for the charitable good.

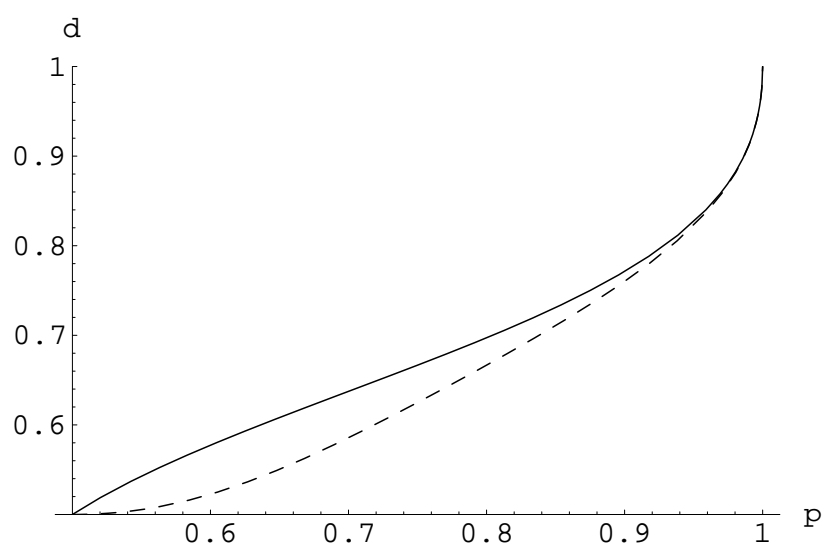

Figure 2: Probability that the charity is good, $d_{C}$, as a function of the quality of detection technology, $p$, in the separating (full line) and the pooling equilibrium (dashed line) 
We observe that the result is valid for all detection technologies, but the impact of certification (the difference between $d_{N C}=\frac{1}{2}$ and $d_{C}$ ) varies: Certification with the worst detection technology, $p=\frac{1}{2}$, has no impact on the market, and the probability that the charity is good is the same as in the market without certification. ${ }^{20}$ As the quality of detection increases, the probability that a charity is good increases. As the quality of detection approaches its maximum, $p \rightarrow 1$, the probability that the charity is good approaches $1, d_{C} \rightarrow 1$, i.e., $\alpha_{C} \rightarrow 0$, and a manager with any preference chooses to run a good charity. Intuitively, with perfect detection, the good charity applies for certification and obtains the certificate with certainty. Thus, the probability that there is a good charity among the noncertified is 0 , and the non-certified charities receive no donations. The manager with any preference, therefore, has no incentive to run such charity.

Figure 2 depicts the impact of certification in the pooling and the separating equilibrium at the fees that ensure the highest effect - pooling at the highest and separating at the lowest possible fee. For all detection technologies, the impact is stronger in the separating equilibrium. The intuition is the following. At the lowest fee ensuring separation, the bad organization does not apply for certification because its expected payoff is too low to cover the costs of certification. Certification at this point fully uses both tools it has to separate the organizations: certification fee and detection technology. Increasing the fee further on decreases the payoff only for the good charity, decreasing the incentives to run a good charity. Decreasing the fee towards the pooling equilibrium increases the payoff for the bad type, increasing the incentives for the manager to choose this type of charity.

\subsection{Alternative disclosure rule}

In this section we examine the impact of a certification system with an alternative disclosure rule: the certifier discloses to the donor not only who has the certificate (C, NC), but also who has applied for certification (A, NA) ${ }^{21}$ Thus, the donor distinguishes three types of charity: the charity that applies and receives the certificate, which receives a donation $g_{A C}$; the charity that applies and fails to receive the certificate, $g_{A N C}$, and charity that does not apply, $g_{N A}$. This alternative disclosure rule is appealing because it seems that it may lead to perfect separation:

\footnotetext{
${ }^{20}$ This results from the fact that with the worst technology the certifier relies solely on the certification fee to induce separation of good and bad organizations; there is only one fee he can charge. He leaves no surplus for the good charities and hence no additional incentives for managers to start a good charity.

${ }^{21}$ We thank Randall Filer for pointing out this alternative.
} 
if only the good charity applies for certification and the donor knows about it, giving to the bad charity drops to zero and giving to the good non-certified charity increases. Nevertheless, none of the certification agencies operating in fundraising markets (Svitkova and Ortmann (2006); Guet (2002)) uses this type of disclosure. We, therefore, explore this alternative and discuss the reasons for the certifier to prefer either of the disclosure rules.

First, we examine the existence of the separating equilibrium, as we expect the new disclosure to have the strongest effect in this case. In the separating equilibrium only the good charity applies for certification, it passes the evaluation and receives the certificate with probability $p$ and fails with probability $(1-p)$. Because the donor observes also who has applied for certification and who has not, and knows that the bad charity never applies, she gives nothing to the charity that has not applied for certification, and 1 to the charity that has applied for certification regardless of the result, i.e., the charity with and without the certificate receives the same donation. But, this presents a very strong incentive for the bad charity to apply: even if it fails the evaluation, the donor would consider it good because she relies on the application information and not on the result of the evaluation. Thus, the bad type also applies, and the certifier is not able to stop him because the donor makes no difference between the certified and non-certified charity - the separating equilibrium does not exist. In terms of the incentive compatibility constraints:

$$
\begin{aligned}
& E[A \mid 0] \leq E[N A \mid 0] \Leftrightarrow(1-p) g_{A C}+p g_{A N C}-c \leq g_{N A} \\
& E[A \mid 1] \geq E[N A \mid 1] \Leftrightarrow p g_{A C}+(1-p) g_{A N C}-c \geq g_{N A} .
\end{aligned}
$$

These two conditions simplify to the following condition on the certification fee, $c$ :

$$
(1-p) g_{A C}+p g_{A N C}-g_{N A} \leq c \leq p g_{A C}+(1-p) g_{A N C}-g_{N A} .
$$

In the separating equilibrium only the good type applies for certification, the payoff to the charity that does not apply, $g_{N A}$, is zero, and the payoffs $g_{A C}$ and $g_{A N C}$ are equal. Thus, condition (12) leaves no room for separation.

In the pooling equilibrium, we assume that the donor maintains her belief that the charity that does not apply for certification is bad, thus, the payoff $g_{N A}$ is zero. This is the major difference between the two certification systems, as in the system with the original disclosure rule, the charity that did not apply for certification could not be distinguished from a charity that applied and failed, thus, it received a positive payoff. Because the "outside" option in this case is zero, the pooling 
equilibrium exists for a larger range of fees than before. We denote the maximum certification fee for which the pooling equilibrium exists $c_{\text {max }, a}$. It is defined by the following constraint holding with equality: ${ }^{22}$

$$
(1-p) g_{A C}+p g_{A N C}-c \geq g_{N A}=0 .
$$

The payoffs to the certified and non-certified charity remain the same as in the original system; see Section (3.2). ${ }^{23}$ The pooling equilibrium exists for a larger range of fees than in the original system, $c_{\max , a} \geq c_{\max , p}$. Moreover, there exists a detection technology, denoted $p_{\max }$, above which the pooling equilibrium exists with the new certification system while the original system leads to a pooling equilibrium with no type applying, $c_{\max , a} \geq c_{\max }$ for $p>p_{\max }{ }^{24}$

The quality of the organization in the market, i.e., the decision of the manager when both systems lead to a pooling equilibrium, $c \leq c_{\text {max }, p}$, is the same in both systems. In this case the systems differ only in the out-of-equilibrium payoff to a charity that does not apply for certification; this has no impact on the equilibrium payoffs, thus, the manager's choice.

In the case when the original certification system leads to a separating equilibrium and the system with the alternative disclosure leads to a pooling equilibrium, $c_{\max , p} \leq c \leq \operatorname{Min}\left\{c_{\max , a}, c_{\max }\right\}$, the equilibrium payoffs differ. In the separating equilibrium, the impact on the quality of the organization is the highest at the minimum fee, $c_{\text {min }}$, which leaves the highest surplus for the good charity while preventing the bad charity from applying. Increasing the fee above $c_{\min }$ leads to a decrease in the surplus of the good charity, decreasing the incentives for the manager to choose a good charity. In the pooling equilibrium, the system with new disclosure, increasing the fee has a negative effect on the good and the bad charity, that also pays the fee. Therefore, the surplus donation to the good charity, and thus the incentive to choose a good charity decreases more slowly than in the separating equilibrium. The difference decreases also as the quality of detection

\footnotetext{
${ }^{22}$ As before, the pooling equilibrium exists as long as the bad type participates (see Section 3.2 .

${ }^{23}$ The only difference occurs in the out-of-equilibrium payoff, $g_{N A}$. The payoffs to the charities that apply for certification are the same in both cases because they are derived under the assumption that both types apply.

${ }^{24} p_{\max }$ increases with the probability that the charity in the market is good: as the probability increases, the payoff to the non-certified charity increases because there is a higher probability that there is a good charity. Thus, the "outside" option for the charity increases, making it more difficult to preserve separation. Also, increasing the probability of the good charity increases the payoff to the good and bad charity in the pooling equilibrium, making the "outside" option, zero, less attractive.
} 
increases, as detection is the main source of information in the pooling equilibrium (predominantly relying on evaluation). Therefore, for fees above $c_{\min }$ there exists a detection technology $p_{a}$ above which the new certification ensures higher quality of the organizations in the market. ${ }^{25}$

In the case when the original certification leads to a pooling equilibrium with no type applying for certification, and the new certification leads to a pooling equilibrium with both types applying, $c_{\max } \leq c \leq c_{\max , a}$, the original system does not change the quality in the market, i.e., it is similar as in a market without certification, while the new system increases quality. If the certification fee is too high, namely, above 1, the alternative disclosure also leads to a pooling equilibrium with no type applying for certification. The situation is similar as with the original disclosure and fee above $c_{\max }$.

The choice of the certifier depends on the budget he has available, the costs of the detection technology, and his objective function. But, if the certifier wants to reach the highest improvement of quality in the market, he shall charge the lowest fee that leads to separation, $c_{m i n}$, and keep the original disclosure rule. He shall turn to the alternative disclosure only if he is forced to charge a higher fee than $c_{\text {max }}$, which would occur, for example, if the technology is too expensive.

\section{Conclusion}

In the present study we modeled the impact of certification on the quality of organizations in the market. We showed that the certifier is, indeed, able to increase the quality by increasing the incentives for the managers to choose a good charity. The impact of certification depends on the design of the certification system - different choices of the detection technology and certification fee lead to different equilibria, which in turn have different effects on the behavior of managers. Specifically, if the fee is too low, both types of charity apply for certification, and the certifier relies solely on the evaluation to distinguish the good from the bad organizations. With a higher fee, it becomes too costly for the bad type to apply for certification: A separating equilibrium arises in which only the good type applies. If the certifier increases the fee further, it becomes too costly even for the good type, and no type applies for certification. The impact is strongest with the lowest fee ensuring separation of good and bad. At this point, the bad charity has no interest in applying,

\footnotetext{
${ }^{25} \mathrm{But}$, this quality remains below the quality ensured by the separating equilibrium with minimum fee, $c_{\min }$.
} 
while the good charity is left with the highest surplus for its operation. The impact increases with the detection technology - an improvement in technology increases the difference in the payoff to the certified and the non-certified charity, increasing the incentives for the manager to choose a good charity.

In the present work we omitted the problem of the costs of detection technology and the certifier's choice of its quality. Nevertheless, we observed that the certification fee has to be within a specific interval to induce separation. If the technology is too costly to be covered from the collected fees, the certifier has to attract additional, external resources. Increasing the fee above the identified limit would lead to a failure of the system as good charities would no longer be able to afford certification, thus, it would cease to exist. If the certifier was not able to attract external resources, he would still do better by providing certification with bad (the worst) technology, as his mere presence (and the fact that he provides a signal for the charities to separate themselves) improves the quality of the organizations in the market. 


\section{References}

Akerlof, G. A.: 1982, Labor contracts as partial gift exchange, The Quarterly Journal of Economics 97(4), 543-569.

Bekkers, R.: 2003, Trust, accreditation, and philanthropy in the netherlands, Nonprofit and Voluntary Sector Quarterly 32(4), 596-615.

Bekkers, R.: 2006, The benefits of accreditation of fundraising nonprofits.

Guet, I. H.: 2002, Monitoring fundraising, a comparative survey of icfo members and their countries, Technical report, ICFO, Berlin.

Ortmann, A., Svitkova, K. and Krnacova, A.: 2005, Certification as a viable quality assurance mechanism in transition economies, Feasibility study on establishing a certification system for nonprofit organizations in the Czech Republic, Transparency International-Czech Republic, Prague, pp. 7-46.

Svitkova, K. and Ortmann, A.: 2006, Certification as a viable quality assurance mechanism: Theory and suggestive evidence. CERGE-EI Working Paper no. 288 .

Weisbrod, B. A.: 1988, The Nonprofit Economy, Harvard University Press, Cambridge, Massachusetts, London, England.

Young, D. R.: 1983, If not for profit, for what?, Heath, Lexington, MA. 
Individual researchers, as well as the on-line and printed versions of the CERGE-EI Working Papers (including their dissemination) were supported from the following institutional grants:

- Center of Advanced Political Economy Research [Centrum pro pokročilá politickoekonomická studia], No. LC542, (2005-2009),

- Economic Aspects of EU and EMU Entry [Ekonomické aspekty vstupu do Evropské unie a Evropské měnové unie], No. AVOZ70850503, (2005-2010);

- Economic Impact of European Integration on the Czech Republic [Ekonomické dopady evropské integrace na ČR], No. MSM0021620846, (2005-2011);

Specific research support and/or other grants the researchers/publications benefited from are acknowledged at the beginning of the Paper.

(c) Katarína Svítková, 2007

All rights reserved. No part of this publication may be reproduced, stored in a retrieval system or transmitted in any form or by any means, electronic, mechanical or photocopying, recording, or otherwise without the prior permission of the publisher.

Published by

Charles University in Prague, Center for Economic Research and Graduate Education (CERGE) and

Economics Institute ASCR, v. v. i. (EI)

CERGE-El, Politických vězňů 7, 11121 Prague 1, tel.: +420 224005 153, Czech Republic.

Printed by CERGE-EI, Prague

Subscription: CERGE-EI homepage: http://www.cerge-ei.cz

Editors: Directors of CERGE and EI

Managing editors: Deputy Directors for Research of CERGE and EI

ISSN 1211-3298

ISBN 978-80-7343-117-4 (Univerzita Karlova. Centrum pro ekonomický výzkum

a doktorské studium)

ISBN 978-80-7344-106-7 (Národohospodářský ústav AV ČR, v. v. i.) 
CERGE-EI

P.O.BOX 882

Politických vězňů 7

11121 Praha 1

Czech Republic http://www.cerge-ei.cz 